\title{
水素の物性と安全な取り扱いについて
}

\author{
繁森 敦*1,†
}

\section{Regarding the Physical Properties and Safe Handling of Hydrogen Gas}

\author{
Atsushi SHIGEMORI ${ }^{* 1, \uparrow}$
}

\section{1. はじめに}

水素は、1766 年に英国の化学・物理学者ヘンリー・キャ ベンディッシュ（Henry Cavendish, 1731-1810）が、強酸 と金属の反応により生成されることを発見し、1783 年にフ ランスの化学者アントワーヌ・ラヴォアジェ (Antoine-Laurent de Lavoisier, 1743-1794) によって、水 を生み出すものを意味する hydrogène（英名 : hydrogen） と命名された。

それから 100 年の時を経て、フランスの作家ジュール・ ヴェルヌは、1874 年に発表した著書「神秘の島」の中で、 石炭の枯渇後には水を水素と酸素に分解してエネルギーを 得る時代が来ることを予言しているが、今まさに水素をエ ネルギーとして使う時代が訪れようとしている。

水素は、可然性の物質であり取り扱いには危険が伴う。 しかし、水素の物性を理解することによって、安全に取り 扱うことが可能である。本稿では、主に水素ガスの物性と その特徵及び安全に取り扱うためのヒントを記載する。

\section{2. 水素の性質}

水素は、常温常圧においては無色・無味・無臭の気体で ある。Table 1 に水素の他、身近に存在する窒素及び燃料と して使用される幾つかの物質について物理・化学的性質の 比較 ${ }^{1)}$ を示す。水素は、燃料として一般的に使用されてい る物質と比較して、可燃限界の範囲が広い、最小着火エネ ルギーが小さい、拡散係数が高く拡散が速い、ガス体積当 たりの燃燒熱が小さいなどの性質を持っている。水素に限 らず可燃性の物質は、これらの性質を良く理解して慎重に

Received August 8, 2019

${ }^{* 1}$ 岩谷産業株式会社 中央研究所

T661-0965 兵庫県尼崎市次屋 3-3-16

Iwatani Corporation, Iwatani R\&D Center, 3-16,

Tsugiya 3-Chome, Amagasaki, Hyogo 661-0965, Japan

† E-mail: sigemori@iwatani.co.jp

(Some figures in this article may appear in colour only in the electronic version)

DOI: $10.2221 /$ jcsj. 55.59
取り扱う必要がある。

水素は可燃性物質であることだけでなく、特徽的な性質 を持つ。その代表的なものをいくつか紹介する。

\section{1 水素火炎}

都市ガスや LP ガスをバーナーで完全燃焼させると火炎 は青色をしているが、これは火炎中の $\mathrm{C}_{2}$ ラジカルや $\mathrm{CH}$ ラジカルが青緑〜青色の化学発光をおこすためである。ま た、ろうそくのオレンジ色の炎は、火炎中で生成した煤粒 子が高温のため黒体輻射で発光しているものである。水素 火炎では、 $\mathrm{C}_{2}$ ラジカル、 $\mathrm{CH}$ ラジカル、煤粒子の発生は無 く、OH ラジカルが発生している。 $\mathrm{OH}$ ラジカルの発光は 紫外域であるため、水素火炎の発光はほとんど目に見えず、 目視による視認が困難である。そのため水素火炎を検知す る場合は、食塩水を噴霧して炎色反応による確認を行うこ とが一般的である。また、 $\mathrm{OH}$ ラジカルの発光による紫外 線を検出する火炎センサーを用いることができる。

\section{2 ガス密度・熱伝導率}

水素は、物質中最小のガス密度と、他のガスと比較して 非常に高い熱伝導率を持つ。発電所では、この物性を利用 してタービン発電機内に水素を封入して冷媒としている。 空気を冷媒とする場合と比べて熱伝導が優れていることか ら、冷却効果が高く、ガス密度が小さいため通風損失等が 少なくなり、タービン発電機の効率が向上する。可燃性ガ スの水素を冷媒として用いるのは、安全面から懸念を覚え るかもしれないが、空気や酸素などの支然性ガスが混合し なければ引火や爆発は発生しないため、機内の水素封入圧 力を陽圧とすることで空気の侵入を防ぎ安全を確保してい る。

\section{3 水素脆化}

水素脆化（hydrogen embrittlement）とは、水素の影響 により材料の強度特性が劣化する現象のことをいい、巨視 的には試験片が延性をなくし破壊することをいう。水素脆 性ともいい、JIS Z 0103 「防せい防食用語」では、「腐食、 酸洗い、電解、溶接などによって生じた水素が金属中に吸 蔵されて、材質がもろくなる現象。遅れ破壊（delayed 
Table 1 Comparison of the physical properties of several gases.

\begin{tabular}{|c|c|c|c|c|c|}
\hline 物性 & 単位 & 水素 & メタン & プロパン & 窒素) \\
\hline 化学式 & & $\mathrm{H}_{2}$ & $\mathrm{CH}_{4}$ & $\mathrm{C}_{3} \mathrm{H}_{8}$ & $\mathrm{~N}_{2}$ \\
\hline 分子量 & - & 2.016 & 16.04 & 44.10 & 28.01 \\
\hline ガス密度（常压、20ㄷ) & $\mathrm{kg} / \mathrm{m}^{3}$ & 0.0838 & 0.651 & 1.87 & $1.25\left(0^{\circ} \mathrm{C}\right)$ \\
\hline 液体密度（常压、沸点） & $\mathrm{kg} / \mathrm{m}^{3}$ & 70.8 & 422.4 & 582 & 808 \\
\hline 臨界温度 & $\mathrm{K}$ & 33.2 & 190.6 & 369.8 & 126.2 \\
\hline 臨界圧力 & $\mathrm{MPa}$ & 1.316 & 4.595 & 4.250 & 3.4 \\
\hline 臨界密度 & $\mathrm{kg} / \mathrm{m}^{3}$ & 31.6 & 162 & 217 & 314 \\
\hline 沸点 & $\mathrm{K}$ & 20.28 & 111.7 & 231.1 & 77.35 \\
\hline 融点 & $\mathrm{K}$ & 14 & 90.4 & 85.5 & 63.14 \\
\hline 定圧比熱 $(C p)\left(\right.$ 常压、2 $\left.25^{\circ} \mathrm{C}\right)$ & $\mathrm{kJ} / \mathrm{kg} \cdot \mathrm{K}$ & 14.31 & 2.23 & 1.667 & $1.039^{5)}$ \\
\hline 定容比熱 $(C V)$ (常圧、25ㄷ) & $\mathrm{kJ} / \mathrm{kg} \cdot \mathrm{K}$ & 10.18 & 1.713 & 1.478 & $0.742^{5)}$ \\
\hline 熱伝導率 (常压、20 $\left.{ }^{\circ} \mathrm{C}\right)^{2)}$ & $\mathrm{W} / \mathrm{m} \cdot \mathrm{K}$ & 0.182 & 0.034 & 0.021 & 0.026 \\
\hline 粘度（常圧、20） & $10^{-6} \mathrm{~Pa} \cdot \mathrm{s}$ & 8.7 & 10.8 & 8.1 & 16.45 \\
\hline 拡散係数 (常压、200 $\mathrm{C} 、$ 空気中 $)^{3)}$ & $\mathrm{cm}^{2} / \mathrm{s}$ & 0.61 & 0.16 & 0.12 & $0.18 \quad\left(0^{\circ} \mathrm{C}\right)$ \\
\hline \multirow{2}{*}{$\begin{array}{l}\text { 総発熱量/高位発熱量 }{ }^{3)} \\
\text { GCV//HHV }\end{array}$} & $\mathrm{MJ} / \mathrm{m}^{3}$ & 12.8 & 40 & 101.9 & - \\
\hline & $\mathrm{MJ} / \mathrm{kg}$ & 142 & 55.9 & 51.8 & - \\
\hline \multirow{2}{*}{$\begin{array}{l}\text { 真発熱量/低位発熱量 }{ }^{3)} \\
\text { NCV/LHV }\end{array}$} & $\mathrm{MJ} / \mathrm{m}^{3}$ & 10.8 & 35.9 & 93.6 & - \\
\hline & $\mathrm{MJ} / \mathrm{kg}$ & 120 & 50.1 & 47.6 & - \\
\hline 発火温度（点)（空気中） & ${ }^{\circ} \mathrm{C}$ & 560 & 600 & 450 & $\begin{array}{l}- \\
\end{array}$ \\
\hline 可燃限界（空気中） & Vol\% & $4.0 \sim 75.0$ & $5.0 \sim 15.0$ & $2.1 \sim 9.5$ & - \\
\hline 最小着火エネルギー & $\mathrm{mJ}$ & 0.02 & 0.28 & 0.24 & - \\
\hline 消炎距離 & $\mathrm{cm}$ & 0.06 & 0.20 & 0.17 & - \\
\hline
\end{tabular}

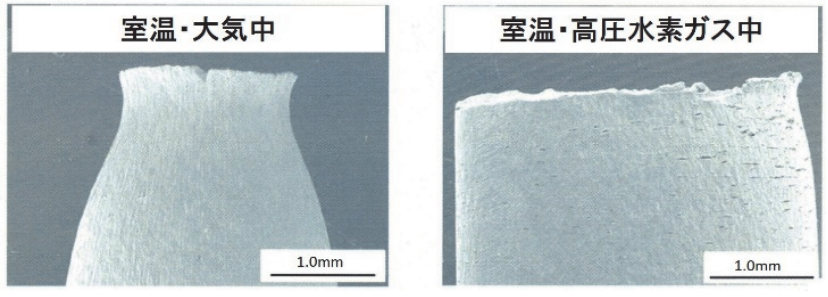

Fig. 1 The fracture conditions after a slow strain rate tensile (SSRT) test of SUS304 stainless steel.

fracture）ともいう。」と定義している。Fig. 1 に、大気中 と高圧水素ガス中における SUS304 ステンレス鋼の低ひず み速度引張試験 (SSRT 試験 : Slow Strain Rate Tensile 試験) 後の破断状況 ${ }^{6)}$ を示す。高圧水素ガス中で試験したサンプ ルには顕著な延性の低下がみられる。高圧水素ガス機器の 安全性や 信頼性を確保するためには、水素脆化の影響を考 慮した材料選択や強度設計が必要である。

\section{3. 水素の安全な取り扱い}

可燃性ガスは、一部の例外を除き単独では燃焼爆発の危 険はなく、空気等の支燃性ガスと一定の割合で混合して可 燃性混合ガス（爆発混合気）を形成すると同時に、火花等 の着火源がある場合に燃焼爆発を起こす。従って、水素を 始めとする可燃性ガスを安全に取り扱うためには、可燃性
混合ガスを作らないこと、及び着火源から隔離することが 有効である。着火源からの隔離に関しては、高圧ガス保安 法 一般高圧ガス保安規則 第 6 条第 1 項第 26 号などにより 火気からの保安距離の確保や使用機器類の防爆対応等が定 められている。

一方、可然性混合ガスを作らないためには、その成分に おける可然性混合ガス領域を知る必要がある。Fig. 2 は、 水素一酸素一窒素の可燃性混合ガス領域を示す三角図 7) である。この図から、水素の爆発範囲を避けるための情報 を得ることができる。例えば、空気中に水素が混入してそ の濃度を増していく場合、水素一酸素一窒素混合ガスの組 成は、空気の組成(1)から水素濃度 100\%の(2)を結ぶ直線上 をたどるように変化する。この直線と可燃性混合ガス領域 との交点の水素濃度は $4 \%$ と $75 \%$ となることから、水素の 空気中での可然限界は下限 4\%〜上限 75\% とされている。

それでは、この三角図を活用して、空気で満たされた容 器を窒素で置換し、安全に水素を充填できる条件を考えて みよう。容器内のガス組成は始め空気であるから、Fig. 2 上では(3)のポイントとなる。窒素を用いて容器内をパージ していくと、矢印の方向にガスの組成は変化していく。酸 素濃度が 5.3\%を下回ると、そこから水素を加えていっても 容器内のガス組成は (4)に沿って変化するため可燃性混合 ガスの範囲には入らない。このように、水素一空気一不活 


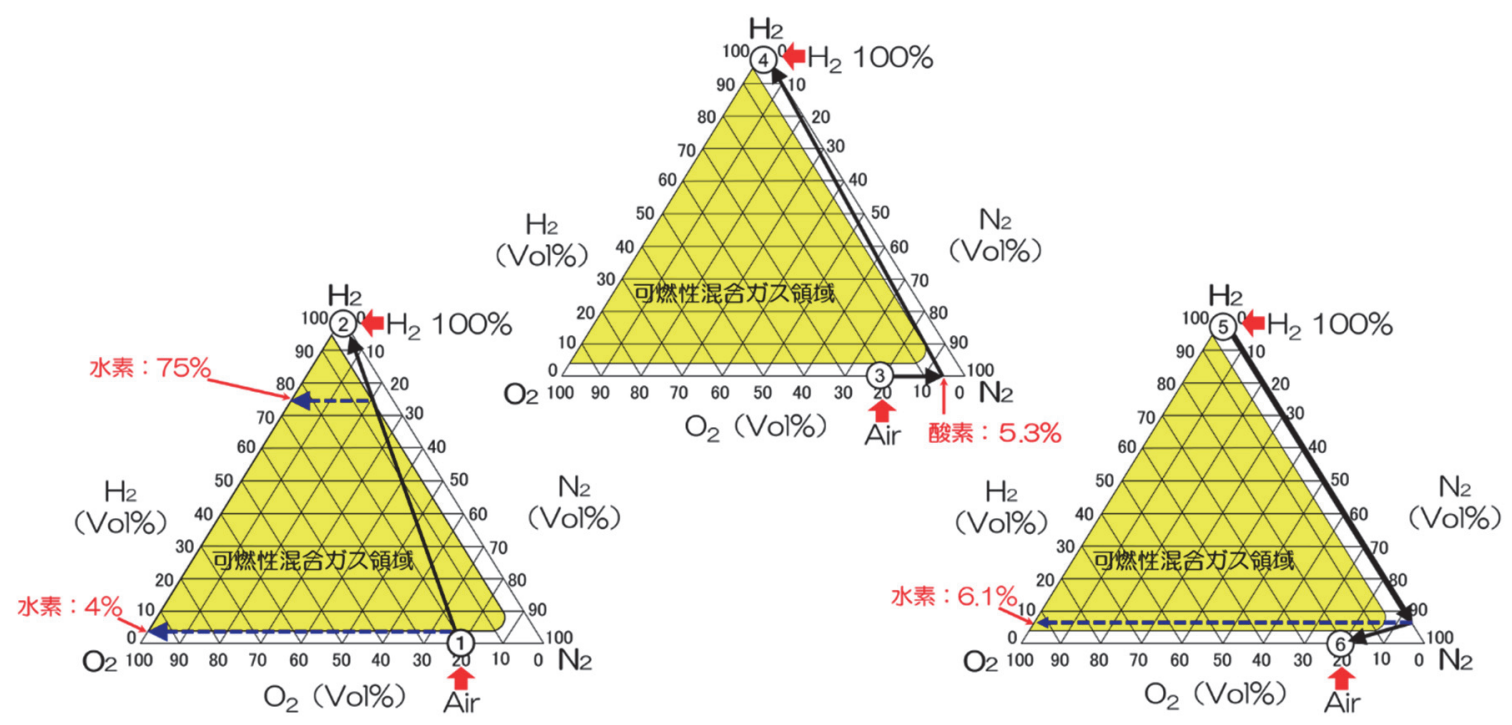

Fig. 2 Flammable mixed-gas area of hydrogen-oxygen-nitrogen component.

性ガス 3 成分系における爆発性消失の限界酸素濃度を、爆 発限界酸素濃度といい、窒素添加の場合は 5.0\%である。空 気で満たされた容器に、安全に水素を充填するためには、 容器内の酸素濃度が $5.0 \%$ 以下となるように窒素希釈を行 えば良い。

希勫に使用する不活性ガスは、一般的に比熱の大きいほ うが 3 成分系の爆発範囲を縮小させるため、少量の添加で 爆発性を抑制することができる。例えば窒素（定圧比熱: 1.043 at $0^{\circ} \mathrm{C}, 1 \mathrm{~atm}$ ) とアルゴン（定圧比熱: 0.523 at $0{ }^{\circ} \mathrm{C}, 1$ atm）を比較した場合、爆発限界酸素濃度は $5.0 \%$ と $3.4 \%$ と なり、窒素の方が添加量を少なくでき爆発予防の面からは 有利である ${ }^{8)}$ 。

逆に水素で満たされた容器を窒素で置換し、安全に開放 する条件を検討することもできる。容器内のガス組成は水 素 100\%であるから、Fig. 2 上では(5)からのタートとなる。 窒素を用いて容器内をパージしていくと矢印の方向にガス 組成は変化していく。水素濃度が $6.1 \%$ を下回ると、そこか ら空気を加えてもガス組成は一6に沿って変化するため可 燃性混合ガスの範囲には入らない。

これらの值を参考にして、容器や配管等を安全に置換す るために必要な最低限のパージ回数を定めることができる。

\section{4. おわりに}

我が国では、水素エネルギー社会の実現を牽引する燃料 電池自動車の普及に伴い水素ステーションの建設が進めら れており、2020 年には 160 箇所、2025 年には 320 箇所の設 置を目指している。今後、水素ステーションだけでなく、 様々な水素インフラが街なかに設置され、水素がより身近 に感じられる時代がやってくる。只、水素に関しては「よ くわからない」「なんだか怖い」と感じている人々が多い のも事実である。これらを払拭していくためには、「安全」
「安心」が重要なキーワードになる。我々水素を取り扱う者 が、水素の「安全」な取り扱い方の周知と、インフラの「安 全」な運用に努めることで、水素が「安全」に使用できる という実績を示し続けることが重要である。更に、フォー ラムや水素エネルギー教室の開催などの水素に関する啓蒙 活動を地道に継続していくことにより、皆が「安心」して 水素と共存できる水素エネルギー社会の実現に貢献したい。

\section{参 考 文 献}

1) 高圧ガス保安協会:「高圧ガス保安技術 第 15 次改訂版」(2018)

2) 佐藤保和：「安全に関わる水素の性質」, 安全工学 44 (2005) 378-385

3) 石本祐樹：「水素拡散、燃焼基礎物性の研究について」, 福岡 水素エネルギー戦略会議研究分科会 (2008) 2

4) (独) 新エネルギー・産業技術総合開発機構:「水素の有効利用 ガイドブック」 13

5) L'Air Liquid: Gas Encyclopedia (1976)

6) 山辺純一郎:「高圧水素ガス中で使用される部材の水素脆化と 強度設計」, 日本溶接協会 FQA2 小委員会 (2017) 4

7) 柳生昭三 :「ガスおよび蒸気の爆発限界」, 安全工学協会 (1977) 10

8）社団法人 産業安全技術協会：「水素混合ガスの安全性に関す る研究 (II)」(1997) 2-3

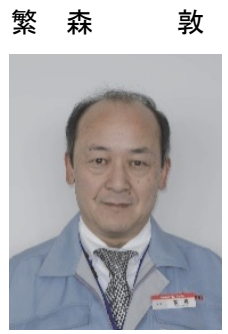

1959 年 2 月 23 日生。 1982 年千葉大学工学 部合成化学科卒業。同年に岩谷産業株式会社 入社。 2008 年よりガス技術・開発室 ガス開発 部長として水素関連の様々な機会開発を担当。 2013 年より岩谷産業中央研究所にて主に水素 関連研究開発に従事。2016 年 10 月より中央研 究所 副所長。低温工学・超電導学会会員。 